\title{
Opinions of Forest Managers, Loggers, and Forest Landowners in North Carolina regarding Biomass Harvesting Guidelines
}

\author{
Diane Fielding, Frederick Cubbage, M. Nils Peterson, Dennis Hazel, \\ Brunell Gugelmann, and Christopher Moorman
}

\begin{abstract}
Department of Forestry and Environmental Resources, North Carolina State University, Raleigh,
\end{abstract} NC 27695-8008, USA

Correspondence should be addressed to Diane Fielding, dianefielding68@gmail.com

Received 7 December 2011; Revised 8 March 2012; Accepted 14 March 2012

Academic Editor: Thomas V. Gallagher

Copyright (C) 2012 Diane Fielding et al. This is an open access article distributed under the Creative Commons Attribution License, which permits unrestricted use, distribution, and reproduction in any medium, provided the original work is properly cited.

\begin{abstract}
Woody biomass has been identified as an important renewable energy source capable of offsetting fossil fuel use. The potential environmental impacts associated with using woody biomass for energy have spurred development of biomass harvesting guidelines (BHGs) in some states and proposals for BHGs in others. We examined stakeholder opinions about BHGs through 60 semistructured interviews with key participants in the North Carolina, USA, forest business sector-forest managers, loggers, and forest landowners. Respondents generally opposed requirements for new BHGs because guidelines added to best management practices (BMPs). Most respondents believed North Carolina's current BMPs have been successful and sufficient in protecting forest health; biomass harvesting is only an additional component to harvesting with little or no modification to conventional harvesting operations; and scientific research does not support claims that biomass harvesting negatively impacts soil, water quality, timber productivity, or wildlife habitat. Some respondents recognized possible benefits from the implementation of BHGs, which included reduced site preparation costs and increases in proactive forest management, soil quality, and wildlife habitat. Some scientific literature suggests that biomass harvests may have adverse site impacts that require amelioration. The results suggest BHGs will need to be better justified for practitioners based on the scientific literature or linked to demand from new profitable uses or subsidies to offset stakeholder perceptions that they create unnecessary costs.
\end{abstract}

\section{Introduction}

Woody biomass from southeastern US forests is expected to play an important role in meeting the nation's future energy needs $[1,2]$. Woody biomass includes small diameter trees, tops, limbs, or otherwise nonmerchantable forest products which are used for energy production and have not been utilized previously. The expansion of woody biomass-based energy raises concerns of forest sustainability, environmental degradation, and negative impacts on biodiversity [3-5]. North Carolina has mandated forest practice guidelines (FPGs), which are linked to recommended forestry best management practices (BMPs) - voluntary guidelines that were developed to protect water quality. However, these guidelines do not specifically address the harvesting of woody biomass, and removing this material has the potential to affect soil productivity, water quality, and forest biodiversity and could negatively affect forest health $[3,6]$. These concerns led to the development of woody biomass harvesting guidelines (BHGs) in five states between 2007 and 2011, and several other states currently have BHGs under consideration [7]. The increasing demand for energy from biomass in proliferation of BHGs makes understanding how stakeholders perceive the suggested guidelines a critical need.

\section{Study Objectives}

The objective of this study was to assess the perspectives of key players in the forestry sector in North Carolina regarding 
BHGs, compare these opinions with the scientific literature on BHGs, and draw conclusions about the implications for biomass markets and policy in North Carolina and the Southeastern US. The forest managers, loggers, and forest landowners interviewed during our study represent groups that will be directly affected by biomass harvesting policies and markets. Their views and willingness to adopt such standards will be crucial in determining the development and success of proposed BHGs.

\section{Biomass Harvesting Guidelines}

To mitigate the impact of biomass removal, BHGs generally recommend leaving 15 to 30 percent of harvestable coarse woody debris (CWD) [7] — which is dead wood material with a small end diameter of at least three inches and a length of at least three feet [8]—on the site following a harvest.

BHGs typically provide guidance on the form of debris retention, either spreading out or piling the woody debris that remains on a harvesting site. Minnesota established BHGs in 2007 which recommended that fine woody debris should be spread out relatively evenly across the site, rather than left in piles. Minnesota BHGs also recommend retaining and scattering 20 percent of the residual tops and limbs following a harvest. Wisconsin recommends retaining and scattering the tops and limbs from 10 percent of trees harvested on the site (one tree of every 10 trees harvested). Maine biomass retention guidelines recommend leaving as much dead wood on site as possible [9].

\section{Literature}

Some literature has addressed opinions about woody biomass either directly or indirectly. We summarize it here briefly and then compare our results with that literature more extensively in the discussion.

4.1. Forest Managers. Few studies have analyzed foresters' perspectives of harvesting woody biomass. Schulte et al. [10] conducted interviews with foresters in the US Midwest to learn more about the market for woody biomass. Forester respondents suggested leaving 33 to 55 percent of residues on site following a harvest for the improvement of soil quality and wildlife habitat. Enrich et al. [11] conducted surveys of foresters across the USA to gather perspectives of opportunities and challenges of harvesting wood for energy. According to respondents, the primary method of harvesting biomass was in conjunction with a conventional harvest. Aguilar and Garrett [12] surveyed foresters and discovered that the main opportunities from utilizing woody biomass were considered to be increased business for loggers and harvesters and an increase in commercial thinnings.

4.2. Loggers. Literature addressing loggers' opinions regarding harvesting biomass is uncommon. Abbas et al. [13] conducted semistructured interviews with Minnesota loggers to better understand the logistics of harvesting woody biomass compared with a conventional harvest. Abbas et al. discuss operational and financial challenges that loggers faced when harvesting small diameter trees which include the use of harvesting equipment that is not designed to handle small woody material and the cost burden of harvesting low-value wood products with expensive machinery. A few studies have addressed logger perceptions of BMPsMilauskas and Wang [14] surveyed loggers in West Virginia and found 89 percent of loggers "always" comply with BMPs. More recently, Bolding et al. [15] surveyed Virginia logging business owners regarding BMPs and discovered that BMPs take significantly more time to be implemented in mountainous regions compared to the coastal plain. Becker et al. [16] reported that forestry stakeholders in the USA including loggers, believed a guaranteed supply of woody biomass was necessary before investments made in harvesting equipment. Communication analyses of the forestry community, particularly the perspectives of loggers regarding environmental policy, have been rare [17].

4.3. Landowners. Many studies have addressed landowner perspectives regarding forest management [17-20], but few have addressed landowner perspectives on BHGs or biomass harvesting. Londo [21] examined Mississippi forest landowners and reported that NIPF landowners had a low level of knowledge regarding BMPs. Many studies have been conducted to determine the effectiveness of forest landowner financial incentive programs [22-24]. Paula et al. [25] surveyed forest landowners in Alabama and found the majority willing to supply timber residues for energy purposes.

Most previous studies regarding woody biomass focused on the costs of harvesting biomass, rather than the experiences and attitudes of the individuals directly involved in the market. A small but growing number of studies explore the perspectives of the forestry community related to the harvesting of woody biomass, but no published research has examined their perceptions of BHGs. This study investigates the opinions of forestry stakeholders who would be directly affected by woody BHGs, if implemented in North Carolina, since they are the ones who would be putting the guidelines into practice.

\section{Methods}

We interviewed forest owners, foresters, and loggers to assess their opinions about BHGs. In addition, we examined the BHGs that have been developed in other states and reviewed the scientific literature about potential environmental problems with biomass harvests that could prompt the need for BHGs.

We sought to obtain and understand the perspectives of North Carolina forest landowners, professional loggers, 
and forest managers about BHGs using a qualitative research approach. We interviewed forest owners, foresters, and loggers to assess their opinions about BHGs. In addition, we examined the BHGs that have been developed in other states and reviewed the scientific literature about potential environmental problems with biomass harvests that could prompt the need for BHGs. We then compared the opinions of respondents in the forest business sector with the literature and approaches taken in other states to assess reasonable policy approaches to BHGs that could be taken in North Carolina or similar southern states.

The individual participants in the study were identified based on key initial contacts and subsequent followups. Five key informants were recommended through sources including the North Carolina Association of Professional Loggers, the State Board of Registration for Foresters, the Association of Consulting Foresters of America, the North Carolina Tree Farm Program, and the North Carolina Forestry Association. The group of key informants included one professional logger, three professional forest managers, and one landowner. The remaining respondents were identified through the snowball sampling method and interviewed to gain insight into the forest industry [26]. Rapport was established with interview subjects while meeting at their homes, places of employment, various logging sites, and public places.

From May 2010 to April 2011, semistructured interviews were conducted with 20 forest managers, 20 loggers, and 20 landowners. We used an interview guide, but the interviews were informant directed, and as a result the respondent was allowed to control the trajectory of the interview and decide which topics of conversation were of importance to them. Consistent with recommended qualitative research practice, the interview guides were allowed to evolve continually throughout the interview process. The questions addressed respondents experience with woody biomass harvesting and their opinions of the operational and financial feasibility of BHGs.

We continued interviewing new informants until saturation, the point where additional interviews did not contribute new information, was reached $[26,27]$. Interviews were recorded and audio files were transcribed into QSR Internationals' NVivo 8 qualitative data analysis software. After the transcription of an interview was completed, a pseudonym was assigned to the speaker to ensure confidentiality. For example, a quotation identified as (Peter) was spoken by an interviewee identified with a pseudonym of Peter.

Qualitative data were analyzed using an inductive approach which allowed common themes to emerge from data gathered from interviews. Transcripts were reviewed and analyzed for emerging themes or patterns [27, 28]. Major themes in each interview were identified through finding repetitions of particular subjects. Transcripts of each interview were coded into different categories using the qualitative data analysis software.
TABle 1: Highest education of North Carolina forest manager, logger, and forest landowner respondents $(n=60)$.

\begin{tabular}{lcc}
\hline & $n$ & $\%$ \\
\hline Less than high school & 1 & $1.7 \%$ \\
High school & 13 & $21.7 \%$ \\
Some college/technical college/trade school & 6 & $10.0 \%$ \\
4-year college degree & 25 & $41.7 \%$ \\
Graduate degree & 15 & $25.0 \%$ \\
\hline
\end{tabular}

\section{Interview Results}

The 60 respondents (Appendix) were predominately male (93\%) with an average age of 55. Most respondents had at least a 4-year college degree (Table 1 ).

The 20 forest managers were consulting foresters (45\%), employees of forestry government agencies (15\%), and forest managers for private companies (40\%). A majority of logger respondents $(65 \%)$ were currently participating in the woody biomass market, meaning they operated a wood chipper or grinder and sold dirty chips (chipped wood containing bark) to a facility that utilized the material for energy production. The delivered price that logger respondents received for dirty chips was in the range of $\$ 15$ to $\$ 30$ per ton with an average of $\$ 21$ per ton $(n=9)$. According to the loggers interviewed, one to three loads (approximately 25 to 75 tons) of woody biomass are typically harvested per acre, although this amount varies greatly depending on stand condition before it is cut. If loggers were not currently participating in the woody biomass market, they were asked to provide reasons for this decision. Loggers blamed the high costs of entry into the chipping business and the lack of market opportunities to sell the material. However, many of the loggers who were not currently harvesting expressed that they would probably add a chipping component in the future.

Forest landowners interviewed owned an average of 1286 acres of North Carolina forestland $(n=20)$ across 17 different North Carolina counties. Nineteen of the 20 forest landowners interviewed had a management plan, and all 19 were currently implementing that plan. Thus this sample seems representative of the most active forest landowners, not the general population of landowners as a whole, who often lack forest management plans. The primary objective landowners held in forest ownership was earning income from timber harvests. Additional dominant objectives included providing wildlife habitat, recreation, and having a natural resource to pass down to their children.

Our sample was drawn from the more involved and progressive members of each of these professional groups. These respondents represent active participants in the forestry sector of the North Carolina Piedmont and Coastal Plain regions, where forests are typically managed for timber rather than aesthetic purposes. Thus, the results 
seem to be a reasonable case in representing the southern timber producers' perspective on additional forest practice regulations.

\subsection{Consensus Themes}

6.1.1. Current Forest Guidelines Are Sufficient. A majority of respondents (96.6\%) believed that North Carolina BMPs had been successful and most commented that the guidelines were "performance based" with "results-driven" standards and high compliance rates and thereby reasonable and had high compliance rates and were reasonable and effective. The majority of the participants believed that harvesting woody biomass could negatively impact water quality; however, they viewed current BMPs as a sufficient protective measure with few exceptions. Lucas, a forest manager, was asked if he believed current BMPs were a success, and he responded, "Yes, I do. Our BMPs are results driven. If you have good results, why change what you are doing? If you look at it, (we are) 97 to 98 percent in compliance of BMPs across the state. To me, that is very successful." Jason, a logger, described why the present positive response of those in the forestry community towards the BMPs can be attributed to the mode of establishment, stating

I think one of the reasons they have been successful is when it started, it was basically as a volunteer implementation program and they figured out real quick the best way to implement these things and the state and everybody else kind of went along with it, working hand in hand with the forestry associations and various groups to come up with plans that would work. It was not forced on everybody, it was kind of volunteered; therefore, they have come up with a solution that has worked.

6.1.2. Biomass Harvesting: Few Modifications to Operations. Respondents expressed that woody biomass harvesting is only an additional component to harvesting with little or no modification to logging operations. During a typical timber harvesting operation in the Southeastern US, material is felled and brought to the logging deck to be sorted into the different products for processing. Respondents explained that when a biomass harvesting component is introduced to a logging operation, there is limited modification to the flow of operations, only the addition of a product at the logging deck. Henry, a landowner, expressed that biomass harvests were not different from current harvest operations, saying "Biomass harvesting is nothing more than a clearcut. We are doing a good job of that now. There should not be any additional harvesting guidelines for biomass." Connor, a logger, said

Biomass harvesting is no different than regular clearcut harvesting. You are going to have the same machinery running on the ground, you will have to observe the same buffer zones and forest practice guidelines-there is no difference-same type of equipment doing the same thing.

6.1.3. Lack of Scientific Research Supporting BHGs. Forest manager, logger, and landowner respondents believed the proposed BHGs were being established by policy makers without the support of objective scientific research. Respondents agreed there was a lack of scientific research supporting claims that harvesting biomass leads to adverse effects on soil, water quality, timber productivity, and wildlife habitat. For example, Felix, a forest manager, stated "There is no document in the literature that I've seen that says that nutrients are diminished by biomass harvesting." Adam reiterated this point saying, "There is no research of (biomass harvesting) causing depletion to soil." Shaun, a logger, was asked about the adoption of BHGs, and he responded, "I do not know what benefits would be...whoever sets those guidelines must have documentation saying why this has got to be done. What is it doing for the land? What are the benefits?" The prevailing opinion of forest landowners was that forest policies are created by political forces or emotions rather than science. For example, Elijah, a forest landowner stated, "A lot of our regulations come from people that do not understand." Another landowner, Stephen, agreed saying, "A lot of people make regulations who do not know anything about forests."

6.1.4. Threats of BHGs to Viability of Biomass Harvesting. Forest managers and loggers regarded the woody biomass market as having very low profit margins and worried that BHGs posed a threat to the viability of biomass harvesting. Forest managers and loggers continually declared how they were constrained by small profit margins due to the undeveloped biomass markets in North Carolina. High transportation costs paired with high fuel costs in harvesting operations were the primary reasons given for why it was not feasible to add a chipping component to a harvesting operation. There were also high costs of entry in the logging business. Adding a woody biomass component to a harvesting operation required extra equipment including a fuel chipper and a chip van. The principal difficulty in adding a fuel chipping component to a timber harvesting operation was the increase in amount of fuel used during the time it takes to harvest the woody biomass material.

Forest managers and loggers expressed concern of the introduction of BHGs worsening the already volatile market for biomass. They communicated that if restrictions were placed on a product that had such a low market value in comparison to other forest products, biomass harvesting would become unattractive and not economically possible. A small number of loggers believed that the adoption of BHGs would not impact their logging operations financially, particularly if they were currently working for a large timber company rather than operating independently since these loggers do not purchase their own timber. 
6.1.5. Accurate Estimation of Debris Is Not Possible. Most forest managers and loggers believed that estimating a particular percent of woody debris to be left after a harvest would be highly problematic from an operational standpoint. Foresters expressed the view that estimating a percentage would not only be logistically challenging but would also increase enforcement costs. Foresters noted that hardwood stands typically have much more debris left on site compared to pine stands, which, if previously thinned and mature, may have very little debris left. Requiring standardized rules of specific percentages of CWD to be left on a site may be difficult with the high degree of variability among harvests. The debris left on a site may depend on characteristics of the stand rather than whether there has been a biomass harvest or not. In addition, forest manager participants believed that violations of BHGs would be a challenge to remediate, particularly if debris was removed without leaving the recommended amount on site.

6.1.6. BMPs Reflect Public Distrust of Forest Industry. One additional theme that emerged from the interviews with forest managers was that they believed BHGs reflected public distrust of forest industry. This idea of "us versus them" describes the polarization between those who work in the woods and those who influence legislation. Forest managers described how they are skeptical of forest guidelines that are politicized and are a result of polemical lobbying by environmental groups. The reason many foresters gave for the lack of collaboration between environmental policy makers and foresters is because individuals working in the forest industry are seen as the "bad people" who cannot be trusted. Phillip explained this notion stating, "Contrary to what some in the environmental community believe, the mission of a forester is not to cut the last tree."

Forest managers also held the belief that forest guidelines often are established by policy makers without communicating with or considering the perspectives of those working in the forest industry. For example, one consulting forester when speaking about forest guidelines stated, "The new buffer rules were put into place without ever talking to foresters" (Patrick). Brad, a governmental agency forester stated, "It is unfortunate that a lot of folks do not want to believe what the foresters say anymore." Lucas, a forest manager in the industry sector, stated

I would say a very high percentage of those people, their opinion of biomass harvesting is not based upon their opinion of biomass harvesting, it is based upon their opinion of logging in general. That is just my opinion but it can be verified by a lot of surveys and things that the general public says and does out there.

The public's view of forestry was not so apparent in logger responses although there were mentions of the disconnect between environmentalists and loggers. One logger, Kevin, explained how he hoped successful BMPs would make a difference in the public's perception of logging saying, "(BMPs) have definitely made a difference and I hope it makes a difference in what the public thinks about loggers."

6.1.7. BMPs Reflect Public Fear of a Desolate Site. The polarization between the public and those in the forest industry is illustrated by one particular vivid image of a desolate site, conjured by "outsiders" to the forest industry. Forest managers described the perceptions of the public visualizing timber harvests as "a vacuum cleaner that sucks out everything," a "concrete floor," or a "pool table." The desolate site rhetoric illustrated a perceived disconnect between the perceptions of the two groups. Our informants may have believed biomass harvesting would evoke this bleak image among the general public or environmental groups because of the fear of environmental degradation and loss of biodiversity of forestlands. However, these types of harvests are seen as only a temporary disturbance in the view of forest managers.

6.1.8. Difficulties of Logging Business. The topic of the current state of the economy and the effect on logging businesses permeated throughout most of the logger participants' interviews. One logger who declined to be interviewed only said, "If something does not change, you are going to see loggers go out of business." Walter stated, "The logger needs some help. That's something you need to put in your write up." He continued, discussing the difficulties of the business,

I am 60 years old and I do not plan to stay in logging. It's too hard; it's nothing I would recommend a young man to do because it's too many rules and regulations right now. The logger do not get paid like he should...I have been in logging 14 years and I have not made a cent in the last two years. It's just getting harder and harder, fuel is high and everything you buy is high... and the logging rates for what you can get for wood is not going up.

Loggers expressed the need for governmental financial and legislative support. Most loggers interviewed owned or worked for small, family-owned logging businesses, and this often left them with small profit margins and little negotiating power.

6.1.9. Definition of Biomass. Forest landowners voiced concern over conflicting definitions of woody biomass in current political discussions. "I am not hearing anything that the BMPs need to be changed to address biomass concerns. Things I am hearing is that we need a definition of what biomass is," remarked Blaine. Duke stated, "I am all for biomass and developing the appropriate definition of it but I am not so sure there should be a limiting definition of what biomass is." Evelyn described how she was not in favor of the definition of woody biomass including whole trees for chipping. Verl, a landowner, also expressed how the lack of a 
clear definition of biomass was a limitation, saying

Everyone is scared to death about what they are going to do on our definitions here. I talked to a fellow yesterday and he was wondering "Why do not we develop the (biomass) market?" And it's simple, who would make the economic investment, not even knowing if standing trees qualifies in the market. Everything is held hostage right now by definitional issues and debate over standards.

6.1.10. Interest in Woody Biomass as an Additional Forest Product. Only two of the twenty landowner interview respondents indicated they had previously had woody debris removed from their property to be used for energy purposes. Landowners who had not previously participated in the woody biomass market communicated interest in the expansion of the market in hopes that previously unmerchantable material could be used and provide additional income. In addition, landowners discussed the benefit of a cleaner site following a woody biomass harvest, which subsequently reduces fire hazards and improves forest health.

The primary reason given by landowners for not participating in the woody biomass market was the lack of market opportunities. Landowners who were aware of woody biomass market developments and recent legislation were eager to participate and be given the opportunity to use previously unmerchantable woody debris to reduce fire hazards and improve forest health.

6.1.11. Government Support of Woody Biomass Market. The majority of landowners agreed that the government should provide financial support for the biomass market and the positive externalities that landowners are providing to the public. Evelyn stated, "For the successful gathering of woody biomass, you're going to have to have tax incentives for loggers, lumber companies and for some landowners." Landowners were interested in federal woody biomass opportunities; however, there was discussion of the inadequacy of previous financial assistance programs such as the federal Biomass Crop Assistance Program (BCAP).

6.1.12. Private Property Rights. Many forest landowners were reluctant to accept any additional guidelines for a variety of reasons including the belief that forest guidelines are "unconstitutional" or are unnecessary since the private landowner should have the freedom in the responsibility over his or her own forest without an increase in environmental protections. Duke captured the overall attitudes of forest landowners toward forest regulations in his comment; "I do not think I need someone to tell me and my forester how to harvest the trees."
6.1.13. Benefits of Biomass Harvesting and BHGs. Two forest managers, three loggers and two of the forest landowners interviewed were not opposed to the adoption of BHGs and instead welcomed these guidelines, contrary to the beliefs of their counterparts. Although these respondents were in the minority, they did express their belief that removing more material from a site as woody biomass could be problematic and that there would be benefits to implementing BHGs. Spencer, a logger, explained "I would not be against (BHGs) because I think everything brought to the forestry field is for a good reason and a good cause. That is what we need, more guidance, guiding us the right way."

6.1.14. Reduced Site Preparation Costs. Forest manager respondents believed that the utilization of biomass can decrease the costs of site preparation for the landowner, which includes planting and bedding to enhance regeneration. Phillip stated, "(Harvesting of woody biomass) provides a cleaner site that is likely to require minimal site prep activity and less investment from a landowner for reforestation." Andrew stated, "The added benefit we get is by getting our site cleaned up better than it otherwise would" which decreases costs of future planting.

6.1.15. BHGs Provide Increased Business for Consulting Foresters. "The more rules that are in place for any forestry, the more confused the landowner will be, the more likely they will be to hire me," Jackson, a consulting forester, stated. A few consulting foresters noted that if BHGs are adopted in North Carolina, their business is likely to benefit since more people will seek the services of a registered forester to clarify and monitor the new guidelines. However, despite the possible personal advantage of increased guidelines, these foresters still opposed potential BHGs.

6.1.16. Proactive Forest Management. Many forest manager respondents thought that better markets for wood products would encourage landowners to be more proactive in forest management. Forest managers placed a great deal of emphasis on forestry decisions and practices being reliant on "the market." Adam, a forest manager, stated, "What causes good forestry practices? The market. We are not dummies and we know there has to be good markets. The better markets we have, the better we will practice good forestry." Michael stated, "If the logging cost made it uneconomical to harvest that landowner's tract, then that closes a market opportunity for that landowner, so tracts do not get harvested and forest management practices do not get implemented."

6.1.17. Reduced Fire Hazard. Forest managers and forest landowner respondents mentioned the reduction in fire hazard as a benefit to the harvest of woody biomass. In the past, prescribed burning was performed after a harvest. However, with the increase of liability and urbanization, 
less burning has been done so there is more debris left on harvesting sites, which can act as a fire hazard, particularly if left in large piles. Removing this debris for energy production can reduce a possible fire and smoke hazard.

6.1.18. Soil Stabilization and Erosion Control. Forest managers, loggers, and landowners expressed concern about biomass harvesting affecting soil quality; however, as mentioned previously, most demanded that sound research document the effects before operations are to be modified. Patricia, a forest manager, stated, "I think (the effect of biomass removal) would happen over time, a consistent removal of biomass in a particular area, over time, sure enough could affect nutrient properties of soil." Max, a logger, was asked about the recommendation of leaving 15 to 30 percent of CWD on site following a harvest, and he responded, "It seems like a fairly reasonable amount to be left, at least there is something being left to stabilize the soil and help the tree growing process. I do not think taking everything off the tract is a good idea." Max continued saying

A lot of the time we are using all of that debris to stabilize the ground, to stop the run off, so if all that debris was getting chipped up and hauled off, then it could create an issue to where the guidelines may have to be changed, it really would - if we started to grind all that stuff up.

Several landowners expressed concern about soil damage and depletion of nutrients from harvesting woody biomass. "If you continue to take the trees off of there and do not leave some of the mass there to regenerate the soil, you are going to deplete the soil" (Brandon). "We do not pay much attention to the soils that take hundreds of years to develop that we can destroy with a single logging operation... I think there needs to be more attention to our soils by BMPs but I would not like to see another set of guidelines imposed on ones that are already there" (Duke). Cory, stated, "You cannot continue taking (woody debris) away and not adding something back to it." He continued saying

Whenever I have had a harvest, I always encouraged my logger to make sure that (debris) was scattered about... I like to see that stuff scattered back on those sites so I do not get an erosion problem. (The debris) will rot and turn back to organic matter. I think that is an excellent guideline.

6.2. Recommendations for BHGs. When asked for suggestions for BHGs, most forest managers took this time to explain why guidelines specifically for biomass harvesting were not necessary. However, there were several recommendations for forestry guidelines to increase focus on soil quality in addition to water quality

Instead of requiring a percentage left on site, I think it should be more related to soil impacts.
In other words, like the FPGs...they do not really tell you how to do it, but the end result is to prevent water pollution and sediment and the streams. So I would think it would make sense for the BHGs to move towards preventing soil impacts. So if the logger has tracked equipment, maybe he can harvest all of the woody debris. If he does not, he has to leave 50 percent of the woody debris, if it is in a wet site (Patrick, forest manager).

Jackson, a consulting forester, recommended leaving a percentage of the ground surface covered with woody debris rather than a percentage of debris left on the ground. Brad, a government agency forest manager, suggested, "The BHG itself should be clear enough that it could be easily interpreted and easily measured, easily monitored." Richard, a consulting forester, believed that a five-year look back strategy would be the best way to determine if biomass harvesting was doing any damage on wildlife and soil before placing restrictions on the operations. He stated, "I think (a five year look back) would be much better than making the regulations onerous on the landowners and the buyers and everybody else."

Loggers who thought leaving 15 to 30 percent of CWD was reasonable believed that it should be done on problem areas. For example, Jack was asked about retaining 15 to 30 percent of CWD on site, and he responded, "It would be possible but only necessary in what we call the main skid trails." Clayton stated, "I would think if there was a slope, you would try to leave (debris) there. If it was more of a flat place, it may not take as much.”

A small number of loggers suggested that guidelines be tailored to the region. For example, Jason suggested that guidelines should be different for the coast where the productivity of timber growth is higher than areas such as the Piedmont. He stated, "It just depends on what part of North Carolina you're talking about. One law will not fit across the whole state." Kevin was asked if North Carolina's BMPs should be adapted to address biomass harvesting and he responded, "I think in certain counties, maybe not in Neuse River or the Roanoke River area, but when you get in the western part of the state, I think the guidelines do need to change. Because we do not have a problem with erosion in this area like you do in Halifax and Warren County."

Jason, a logger, also offered advice for the formulation of guidelines saying

(Policy makers) need to visit everybody who is in the biomass business now and get some comments from every single one of them before they come out with a set of rules. And they need to be loggers, they need to have had experience logging, they have to be able to show criteria. As long as you do not just give somebody a briefcase and say, here now you're the expert 
on biomass, and he do not know his damn way from Raleigh to the coast-I'm against that. But if the guy is legitimately trained and knows what he is doing, I am for it.

Landowners were asked if they had any recommendations for BHGs, and a variety of responses and suggestions were given. Some landowners took this opportunity to insist that additional forest guidelines were unnecessary. For example, Duke commented, "I am not sure you can regulate good forestry." A few landowners discussed enforcement and how without it guidelines were futile. Thomas stated

If you do not have enforcement capabilities of guidelines or rules or regulations with teeth in them that are regularly used, somebody will do whatever they feel is in their best interest to do. So if you are going to have guidelines, have the gumption to have monitoring and enforcement, somewhere or another.

A few landowners suggested that for the woody biomass market to expand, woody material must be gathered for energy at the time of harvest rather than later. For example, Evelyn stated, "There does not need to be a delay, they don't need to come in a year later and gather the woody biomass. . Come on in right behind, get it done at one time." Elijah stated, "I think it would be much more economical to be there on the spot with the logger doing it or a contractor doing it while the logger is there, as far as going in to the guideline."

6.3. Forestry Organizations. Both the North Carolina Forestry Association (NCFA) and the North Carolina Association of Professional Loggers (NCAPL) are important trade associations in the state, and several respondents were confident that guidelines regarding harvesting woody biomass would not be adopted because of these organizations' influence on the forestry sector and legislature. Jackson, a forest manager, stated

Legislation will never pass in North Carolina. It is not going to. I think if you go back and look at the teeth we are trying to put in the board of registration laws for registered foresters, the forestry association has fought it all the way. Anything that requires a logger to learn about something, or spend more money, the forestry association fights you all the way.

Max, a logger, explained the NCAPL saying

We have those guys as watchdogs and they are trying to get wood pellet companies into the state. Another thing too, with having that organization watching out for us, we don't see anything too intense as far as rules and regulations being passed. I do not think they would let it happen; they would do something to put a stop to it. So it's nice to have those guys and organizations in our corner as far as rules and regulations.

\section{North Carolina Forestry Sector Opinions versus Biomass Harvesting Impacts Research}

Our research interviews did not provide any background of biomass harvesting literature and science before or during the interviews. We were seeking the opinions of North Carolina forest landowners and professionals based on their existing knowledge and awareness of the issue. However, our review of literature on biomass harvesting impacts, the adoption of BHGs in other states, and the perceived fears of adverse environmental impacts by the public and environmental groups suggests discrepancies between the opinions of the forest business sector informants and perceptions of other groups concerned about biomass harvesting and its environmental impacts. These differences and some similarities are examined in this section.

7.1. Current Guidelines Are Sufficient for Woody Biomass Harvests. Our interview findings suggest broad support for BMPs among forestry stakeholder groups, which did not translate into support for BHGs. As in other studies, we found that respondents considered BMPs to have been successful for their effectiveness [29] and had high compliance rates $[14,30,31]$. Respondents believed that current guidelines were not only successful, but also sufficient in the protection of forest resources during harvesting operations. The widespread acceptance of BMPs may explain the perceived benefits of the current forest guidelines [3234] and opposition to any additional guidelines since they are deemed unnecessary. There will likely be resistance from the North Carolina forestry community if BHGs are implemented. Perspectives of forestry stakeholders in states which have adopted BHGs would be beneficial to understanding the willingness to accept novel forest guidelines.

The perceived similarity between traditional operations and biomass operations also may explain why all groups believed that biomass harvesting should not be treated separately from a conventional harvest in terms of the guidelines applied. During a typical logging operation in the Southeast, after the tree is felled, the whole tree is usually skidded to the log deck where the limbs and tops are removed and the wood is sorted for each market. Adding a woody biomass harvesting component is the addition of a chipper and a chip van which are brought to the logging deck. The material which will be used for woody biomass is put through the chipper at the logging deck, and the operational process of harvesting trees in the woods is not altered.

Therefore, in the southeastern US, harvesting biomass does not significantly change operations in terms of harvesting material; it only supplies an additional product. However, harvesting operations differ across regions. For 
example, in the northeastern US, harvesters frequently leave the limbs and tops where the tree is felled, rather than bringing the material to the logging deck. These variations must be considered when adopting guidelines that may have been created for a region with different harvesting methods.

7.2. Lack of Scientific Research Supporting BHGs. Our findings indicate that the North Carolina forestry community does not believe the available science related to woody biomass harvesting is sufficient for the adoption of additional forest guidelines. All three of the groups agreed on the importance of the scientific method to achieve results that supported the creation of BHGs; however, they expressed concern that forest policy may be based on emotions and political expediency and ignore science and the practical constraints of harvesting operations. Similar studies found the same general attitudes towards new forest policy. For example, Holt [35, page 31] discovered that forest stakeholders in Oregon hoped that the biomass industry was "not politicized and driven by politics" and instead based upon funding and informed by science. Eliason et al. [36] found that natural resource professionals were wary of new guidelines and wanted to "understand the reasons" and "understand the end result...the end goal" before new forest guidelines were to be adopted. Dietz et al. [37] documented that forest professionals believed the public had little knowledge of forests. Similarly, Dirkswager et al. [38] interviewed landowners and found them to believe that policy makers who formulated biomass harvesting policies did not understand the economics of harvesting timber.

There is a large body of research that has explored the science behind the dynamics of woody biomass and the detrimental effects that harvesting the material could have on forest ecosystems. Harmon et al. [39] documented snags and downed coarse woody debris to be important to forest ecosystems and critical to wildlife habitat. Downed CWD has been shown to benefit a variety of organisms, including invertebrates, vertebrates, fungi, and plants $[40,41]$. Downed CWD may also be important for nutrient retention [39]. It has been shown to limit erosion by reducing overland flow [42].

Despite the ample evidence for the importance of specific habitat elements (e.g., CWD, snags, cavity trees, etc.) to forest biodiversity, there is still reluctance among the forestry community to accept additional regulations to protect forest ecosystems in the event of increased biomass harvests. Conflict between practitioners, policy makers, and researchers likely emerges from efforts to set a specific number or amount of each habitat elements that should remain on an acre of forest land. This is comparable to the results of both Botkin [43] and Peterson [44] who found that the scientific method often exacerbates, rather than lessens, environmental conflict.

The growth in woody biomass markets may significantly increase the amount of CWD that is harvested [45], and Moorman et al. [46] suggest that the extraction of woody biomass may alter the dynamics of CWD and lead to lower amounts of the material due to shorter harvest rotations. This reduction in downed CWD could have detrimental effects on many species of wildlife including mice, small snakes, lizards, and salamanders [39, 47]. The Pennsylvania BHGs state that "good biomass practices can enhance and improve forestland; poor practices can damage and devalue it" [48, page 30]. Similarly, Hess and Zimmerman [45, page 6] discovered there to be a consensus among experts that the "absence of downed woody debris would be detrimental to biodiversity and ecological processes."

Some ambiguity in the science addressing the effects of woody biomass harvesting and the high level of conflict between interest groups suggests that it will be difficult to implement BHGs, since there is neither a top-down nor bottom-up pressure and little support from the interest groups interviewed here [49]. Per Matland [49], the coalition of local level actors will determine the policy implementation depending on their influence and strength. The resistance of loggers, landowners, and foresters to more BHGs will impede their adoption. Environmental interest groups and agencies may support the rules, but it appears they will face fairly pervasive opposition. The new conservative legislature in North Carolina, and much of the South, will also make development of new laws or even new BHG guidelines difficult.

On the other hand, a recent court ruling in North Carolina that all woody materials, even whole trees, qualify as biomass, along with the rapid expansion of more wood pellet plants, may cause enough pressure that BHGs will be developed. Also, all large energy and forestry companies already have corporate environmental policies, staff, and programs. Large companies also are ranked on their sustainability efforts by many sources, such as the Dow Jones Sustainability Index, which evaluates the sustainability performance of the companies listed on the Dow Jones and will surely require them to have proactive policies to prevent adverse impacts during biomass harvests.

\subsection{Threats of BHGs to Viability of Biomass Harvesting.} Woody biomass is currently a low-value product, and we found that respondents believed the market was too volatile to introduce further guidelines on the harvesting process. Forest managers and loggers identified the transportation costs of woody biomass as one of the most challenging factors of adding a chipping component to an operation. These findings are in line with those of Aguilar and Garrett [12], who reported that the costs of harvesting and transporting were identified by professional forest managers as the biggest challenge to harvesting woody biomass as a renewable energy feedstock.

Similarly, Dirkswager et al. [38] conducted a phone survey with logging business owners in Minnesota and found low product prices, high equipment and fuel costs, the lack of material, and environmental regulations were primary barriers in the harvesting of biomass. They also found that landowners believed increased forest regulations would threaten sustainability in timber harvesting. It is not clear which group will bear costs of BHGs. Loggers will 
spend more time implementing BHGs which will result in increased fuel costs and equipment usage. This suggests that the price landowners receive for woody biomass material may be reduced with BHG implementation.

7.4. BMPs Reflect Public Distrust of Forest Industry. Respondents believed that forest guidelines often were formulated by policy makers based on the public's distrust of logging rather than sound science. A review of the literature suggests the polarization between those in the forest industry and the public is not a new concept. Foresters have had decreasing public esteem for years. For example, the association of British Columbia Professional Foresters sponsors opinion polls of the public's perception of foresters each year and found that in 1997, 66 percent of the public believed it was "very important" to have forestry reserved for professional foresters. This percentage decreased each year, and in 2002, this number dropped to 40 percent [50].

Thomas [51] as cited in Luckert [52] wrote of American foresters and stated, "Twenty or so years ago, foresters were among the most respected and trusted professionals in the United States. Sadly that is no longer so." Keefer et al. surveyed loggers in Pennsylvania, and 70 percent felt the "negative public image of the logging industry" was the most significant pressure faced in the logging business [53, page 91]. These sentiments of forest managers and loggers illuminate the isolation and lack of effective communication between those working in the forestry industry and the public.

Forest managers frequently mentioned the public's fear of having a timber harvest site left as a denuded landscape of stumps. This perception was a reason forest managers cited as why policy makers believed that biomass harvesting needed to be regulated although, according to respondents, this bleak observation was only a temporary scene which is quickly replaced by new growth of the forest. The public's fear of a desolate site is explored throughout the literature and can be explained by the public's negative perception of clearcutting. Egan et al. [54] investigated tree farmer opinions in West Virginia and discovered that 55 percent believed clearcutting should be banned. Bliss [55] investigated the public's perceptions of clearcutting and found that several opinion polls have continually reported the widespread disapproval. Bliss also describes that Americans find clearcutting to be "aesthetically offensive" and the practice leads to conjured images of vast deforestation and degradation. Understanding the relationship between the public's negative view of forestry and forest regulations is necessary in the development of forest guidelines.

7.5. Logging Economic Hardships. The economic challenges of operating a logging business during a poor economy were discussed frequently by loggers throughout the interview process. Recent literature discusses the difficulties of the logging business. For example, Bolding and others [15] documented the challenges of logging in Virginia which include an aging workforce, recent mill closures, and volatility of the market. Egan and Taggart [56] found 69 percent of loggers surveyed in New England did not encourage their children to enter the logging business, and only 51 percent of respondents stated that they would still be logging in five years. Loggers are constrained by low prices, lack of markets, and high operation and fuel costs and expressed the desire to capitalize on available business opportunities. This suggests that the poor economic climate for loggers paired with the volatile woody biomass market will make it difficult for the forestry community to accept any regulations that further constrain profit margins for loggers. Additional research is needed to better understand the economics of harvesting operations using BHGs.

7.6. Definition of Biomass. Our results show that forest landowners are concerned with the conflicting definitions of woody biomass in political discussions. A number of landowners believed that definitions of woody biomass should not be restrictive based on the type of material or if the material is located on public or private land. A small number of landowners mentioned that they did not want the woody biomass definitions to include whole-tree chipping. There have been ongoing political debates regarding the formulation of a clear definition of woody biomass, particularly as it relates to renewable energy standards. Benjamin et al. [3] noted that the terms "forest biomass" and "biomass harvests" often create confusion among forest professionals and those in academia. Aguilar and Garrett [12] surveyed state foresters, state energy biomass contacts, and members of the National Council of Forestry Association Executives to understand perspectives of the definition of biomass and found that respondents believed the definition of biomass "should not differentiate between naturally regenerated forest stands and plantations or private and public forestlands." The current ambiguity in woody biomass definitions, particularly in North Carolina legislation, will likely impede the implementation of additional forest guidelines.

7.7. Private Property Rights. Forest landowners were adamant about their private property rights and believed they deserved the freedom to manage their forest as they wished, without an increase in environmental protections. These perceived landowner rights were the main reasons given for landowner respondents' opposition to BHGs. These results are comparable to Williams and others [57] who found a majority of Arkansas NIPF landowners believed they should have the ability to use their land as they chose without regulations although the landowners supported environmental protection.

In contrast, Bliss et al. [58] surveyed southeastern landowners and reported 76 percent felt their property rights should be limited if it was essential for the protection of the environment. In a similar study, Bliss et al. [18] reported rural residents, urban residents, and forest landowners believed that private property rights were necessary but secondary to environmental protection, and there was no significant difference between the groups. These two studies 
suggest landowners may support BHGs despite the opposition to additional forest protections, if guidelines ensure the protection of the forest.

\section{Conclusions}

Forest managers, forest landowners, and loggers in North Carolina were reluctant to accept any additional forestry guidelines, particularly related to the harvesting of woody biomass, due to the perceived economic and social impact of increased regulation. Reconciling these perspectives on woody biomass harvests with public concern over environmental impacts is necessary for effective expansion of biomass markets, and public policies that will facilitate the use of this potentially important natural resource.

Most forest manager, logger, and landowner respondents in this study believed that there was not sufficient scientific literature or evidence to support claims that biomass harvesting threatens wildlife habitat or ecosystem function. Available science related to the negative effects of woody biomass harvesting is either not well known by the forestry community or not believed. This suggests that the introduction of science has had little practical influence on the perceptions, or at least that literature has not been extended well to the forestry sector respondents in the field.

The opposition to BHGs among forest managers, loggers, and landowners parallels the resistance that the public typically has for additional environmental policies and regulations. However, this study provided unique results in that respondents expressed positive opinions and acceptance of BMPs yet antipathy towards additional forest guidelines. The differences among sectors were not always as anticipated. For example, consulting foresters could potentially profit from additional forest guidelines yet still opposed BHGs. Loggers would likely incur more costs from the implementation of BHGs, at least in the short run, than landowners, yet were more positive regarding adoption of BHGs.

Our interviews in North Carolina, and indeed the general literature, have not examined the role of market factors such as corporate social responsibility, environmental management systems (EMS) such as ISO 14000, external corporate sustainability rankings for investors and consumers, and forest certification in driving the demand for BHGs. Large electric and wood chip companies have extensive environmental management programs and must submit and demonstrate environmental compliance in all their activities. Woody biomass production will be required to meet these same strictures, and BHGs, forest certification, chain of custody, or other approaches surely will be necessary to obtain investor approval and bank financing for these projects. Thus the market drivers may lead the traditional forestry sector toward BHGs despite stakeholder concerns.

The findings from this qualitative study point to several recommendations in developing appropriate forest policies and incentives for practicing sustainable forestry on privately owned land. Recommendations for policy makers include the following. (i) Bridge the divide between public and the forestry community's discourse regarding biomass policy to lessen conflict between environmental groups, forest managers, forest landowners, and loggers.

(ii) Consider the forestry community's reluctance to adopt additional guidelines.

(iii) Use market drivers of environmental management systems, corporate sustainability rankings, and certification to convey the need for BHGs.

(iv) Develop guidelines based on research and focus on harvesting impacts that are not already covered by BMPs, such as biodiversity, wildlife, and site productivity.

(v) Provide enhanced outreach and extension about the science regarding potential adverse impacts of biomass harvesting and the role of BHGs in ameliorating problems.

(vi) Develop standard protocols for measuring the amount of biomass initially and the amount to be left on site.

(vii) Specify local relevance of woody BHGs.

(viii) Define the term woody biomass clearly in appropriate policy.

(ix) Engage all stakeholders in discussions and development of BHGs, including environmental nongovernment organizations and bioenergy companies.

(x) Develop new, low-cost, innovative outreach methods for young and "tech-savvy" landowners, foresters, and loggers to participate in biomass markets and BHGs.

Future research needs to include assessing the perceptions of environmental groups and energy companies and users regarding BHGs. Other future studies could include a cost analysis to assess the financial impact of BHGs on logging operations. In conclusion, this study can aid in making informed policy decisions around BHGs that are not only sustainable, but also integrate the suggestions of the forestry community and scientific literature into guideline formulation. This information can also contribute to management decisions regarding sustainable BHGs and certification standards. The qualitative data and recommendations provided can be used for further education and outreach for the southeastern forest community and for the evaluation of specific solutions for the barriers of harvesting woody biomass.

\section{Appendix}

See Tables 2, 3, and 4 . 
TABLE 2: Forest manager respondents.

\begin{tabular}{|c|c|c|c|c|c|}
\hline & Pseudonym & Age & Gender & Education & Job type \\
\hline 1 & Ronald & 49 & M & Graduate school & Consultant \\
\hline 2 & Jonathan & 53 & $\mathrm{M}$ & College & Consultant \\
\hline 3 & Patrick & 53 & $\mathrm{M}$ & College & Consultant \\
\hline 4 & Peter & 51 & M & Graduate school & Government agency \\
\hline 5 & Beverly & 44 & $\mathrm{~F}$ & College & Private industry \\
\hline 6 & Joseph & 39 & M & College & Private industry \\
\hline 7 & Andrew & 53 & M & College & Private industry \\
\hline 8 & Wayne & 58 & M & Graduate school & Consultant \\
\hline 9 & Patricia & 39 & $\mathrm{~F}$ & College & Private industry \\
\hline 10 & Jackson & 54 & M & College & Consultant \\
\hline 11 & Wesley & 38 & M & College & Consultant \\
\hline 12 & Michael & 49 & M & Graduate school & Government agency \\
\hline 13 & Brad & 38 & M & College & Government agency \\
\hline 14 & Matthew & 55 & M & College & Consultant \\
\hline 15 & Adam & 62 & M & College & Consultant \\
\hline 16 & Robert & 56 & M & College & Consultant \\
\hline 17 & Lucas & 56 & M & Graduate school & Private industry \\
\hline 18 & James & 48 & M & Graduate school & Private industry \\
\hline 19 & Phillip & 60 & M & College & Private industry \\
\hline \multirow[t]{3}{*}{20} & Felix & 56 & $\mathrm{M}$ & Graduate school & Private industry \\
\hline & Average & 50.5 & & & \\
\hline & Standard deviation & 7.4 & & & \\
\hline
\end{tabular}

TABLE 3: Logger respondents.

\begin{tabular}{|c|c|c|c|c|c|}
\hline & Pseudonym & Age & Gender & Education & Owns chipper \\
\hline 1 & Spencer & 50 & $\mathrm{M}$ & College & No \\
\hline 2 & Walter & 60 & M & 8th grade & No \\
\hline 3 & Clayton & 45 & M & High school & No \\
\hline 4 & Blake & 56 & M & Some college & Yes \\
\hline 5 & Hugh & 52 & M & College & Yes \\
\hline 6 & Drew & 50 & M & Some college & No \\
\hline 7 & Harrell & 59 & M & Some college & Yes \\
\hline 8 & Anthony & 52 & M & High school & Yes \\
\hline 9 & Austin & 32 & M & High school & Yes \\
\hline 10 & Max & 55 & M & Some college & No \\
\hline 11 & Shaun & 75 & M & High school & Yes \\
\hline 12 & Connor & 67 & M & College & No \\
\hline 13 & Owen & 51 & M & High school & Yes \\
\hline 14 & Alex & 31 & M & Some college & Yes \\
\hline 15 & Kevin & 54 & M & High school & No \\
\hline 16 & Charles & 47 & M & High school & Yes \\
\hline 17 & Jason & 63 & M & Graduate school & Yes \\
\hline 18 & Gary & 40 & M & High school & Yes \\
\hline 19 & Jack & 51 & M & College & Yes \\
\hline \multirow[t]{3}{*}{20} & Edward & 48 & $\mathrm{M}$ & High school & Yes \\
\hline & Average & 51.9 & & & \\
\hline & Standard deviation & 10.5 & & & \\
\hline
\end{tabular}


TABLE 4: Landowner respondents.

\begin{tabular}{|c|c|c|c|c|c|c|}
\hline & Pseudonym & Age & Gender & Education & Acreage of woodlands & Management plan \\
\hline 1 & Duke & 76 & M & Graduate school & 164 & Yes \\
\hline 2 & Cory & 59 & M & College & 107 & Yes \\
\hline 3 & Mark & 44 & M & Graduate school & 180 & Yes \\
\hline 4 & Stephen & 71 & M & College & 3000 & Yes \\
\hline 5 & Ronald & 67 & M & College & 355 & Yes \\
\hline 6 & Thomas & 68 & M & College & 250 & Yes \\
\hline 7 & Ken & 55 & M & Graduate school & 70 & Yes \\
\hline 8 & Brandon & 67 & M & College & 5000 & Yes \\
\hline 9 & Elijah & 72 & M & High school & 750 & Yes \\
\hline 10 & Evelyn & 59 & $\mathrm{~F}$ & Graduate school & 650 & Yes \\
\hline 11 & Blaine & 59 & M & Graduate school & 2500 & Yes \\
\hline 12 & Verl & 60 & M & Graduate school & 125 & Yes \\
\hline 13 & Henry & 48 & M & Graduate school & 2900 & Yes \\
\hline 14 & William & 73 & M & Some college & 250 & Yes \\
\hline 15 & Simon & 52 & M & High school & 25 & Yes \\
\hline 16 & Margaret & 69 & $\mathrm{~F}$ & High school & 110 & Yes \\
\hline 17 & Todd & 80 & M & Graduate school & 94 & Yes \\
\hline 18 & Chuck & 65 & M & High school & 400 & No \\
\hline \multirow[t]{3}{*}{19} & Roger & 58 & $\mathrm{M}$ & College & 7500 & Yes \\
\hline & Average & 63.2 & & & 1285.7 & \\
\hline & Standard deviation & 9.6 & & & 2041.3 & \\
\hline
\end{tabular}

\section{Acknowledgments}

The authors would like to thank the forest manager, logger, and landowner interview respondents who shared their opinions with them; the reviewers who provided helpful insight; the United States Department of Agriculture (USDA) and the Agriculture and Food Research Initiative (AFRI) for funding this research.

\section{References}

[1] C. S. Galik, R. Abt, and Y. Wu, "Forest biomass supply in the southeastern United States-implications for industrial roundwood and bioenergy production," Journal of Forestry, vol. 107, no. 2, pp. 69-77, 2009.

[2] R. C. Abt, K. L. Abt, F. W. Cubbage, and J. D. Henderson, "Effect of policy-based bioenergy demand on southern timber markets: a case study of North Carolina," Biomass and Bioenergy, vol. 34, no. 12, pp. 1679-1686, 2010.

[3] J. G. Benjamin, R. J. Lilieholm, and C. E. Coup, "Forest biomass harvesting in the Northeast: a special-needs operation," Northern Journal of Applied Forestry, vol. 27, no. 2, pp. 45-49, 2010.

[4] D. Damery, M. Kelty, D. Benjamin, and R. J. Lilieholm, "Developing a sustainable forest biomass industry: Case of the US Northeast," Ecology and Environment, vol. 122, pp. 141152, 2009.

[5] Pinchot Institute and The Heinz Center, Forest Sustainability in the Development of Wood Bioenergy in the U.S., The Pinchot Institute for conservation and The H. John Heinz III Center for Science, Economics and the Environment, Washington, DC, USA, 2010.
[6] Southern Group of State Forester's, "Woody Biomass Harvesting Guidelines," Services, Utilization and Marketing Task force and Water Resources Committee Technical Paper, 2009.

[7] A. M. Evans, R. T. Pershel, and B. A. Kittler, Revised Assessment of Biomass Harvesting and Retention Guidelines, Forest Guild, Santa Fe, NM, USA, 2010.

[8] C. W. Woodall and V. J. Monleon, Sampling Protocol, Estimation, and Analysis Procedures for the Down Woody Materials Indicator of the Fia Program, GTR-NRS-22, USDA Forest Service, Northern Research Station, Newtown Square, Pa, USA, 2008.

[9] J. G. Benjamin, Considerations and Recommendations for Retaining Woody Biomass on Timber Harvest Sites in Maine, University of Maine, Maine Agricultural and Forest Experiment Station, Orono, Me, USA, 2010.

[10] L. J. Schulte, L. J. Tyndall, R. Hall, and K. Grubh, "Rapid assessment of woody biomass capabilities in three regions of the U.S. Midwest," 2008, http://www.nrem.iastate.edu/ landscape/Publications/FinalWoodyBiomassReport.pdf.

[11] A. Enrich, D. Greene, and S. Baker, "Status of Harvesting \& Transportation for Forest Biomass - Preliminary Results of a National Survey of Logging Contractors, Procurement Foresters, Wood Dealers and Forest Managers," 2009, http://frec .vt.edu/cofe/documents/2010/Enrich_COFE_BiomassSurvey .pdf.

[12] F. Aguilar and H. E. Gene Garrett, "Perspectives of woody biomass for energy: survey of state foresters, state energy biomass contacts, and national council of forestry association executives," Journal of Forestry, vol. 107, no. 6, pp. 297-306, 2009.

[13] D. Abbas, D. Current, K. Brooks, and D Arnosti, "Chapter 6: The Loggers' Voice in Harvesting Fuel: Cutting Costs and 
Reducing Forest Fire Hazards Through Biomass Harvest," The Institute for Agriculture and Trade Policy, 2008, http://www.upwoodybiomass.org/downloads/harvesting_fuel _arnosti_et_al_2008_report.pdf.

[14] S. J. Milauskas and J. Wang, "West Virginia logger characteristics," Forest Products Journal, vol. 56, no. 2, pp. 19-24, 2006.

[15] M. Chad Bolding, S. M. Barrett, J. F. Munsell, and M. C. Groover, "Characteristics of Virginia's logging businesses in a changing timber market," Forest Products Journal, vol. 60, no. 1, pp. 86-93, 2010.

[16] D. R. Becker, S. M. McCaffrey, D. Abbas, K. E. Halvorsen, P. Jakes, and C. Moseley, "Conventional wisdoms of woody biomass utilization on federal public lands," Journal of Forestry, vol. 109, no. 4, pp. 208-211, 2011.

[17] T. R. Peterson and C. C. Horton, "Rooted in the soil: how understanding the perspectives of land-owners can enhance the management of environmental disputes," Quarterly Journal of Speech, vol. 81, no. 2, pp. 139-166, 1995.

[18] J. C. Bliss, S. K. Nepal, R. T. Brooks, and M. D. Larsen, "In the mainstream: environmental attitudes of mid-south forest owners," Southern Journal of Applied Forestry, vol. 21, no. 1, pp. 37-43, 1997.

[19] D. D. Dutcher, J. C. Finley, A. E. Luloff, and J. Johnson, "Landowner perceptions of protecting and establishing riparian forests: a qualitative analysis," Society and Natural Resources, vol. 17, no. 4, pp. 319-332, 2004.

[20] M. K. Measells, S. C. Grado, H. G. Hughes, M. A. Dunn, J. Idassi, and B. Zielinske, "Nonindustrial private forest landowner characteristics and use of forestry services in four southern states: results from a 2002-2003 mail survey," Southern Journal of Applied Forestry, vol. 29, no. 4, pp. 194199, 2005.

[21] A. J. Londo, “An assessment of Mississippi’s nonindustrial private forest landowners knowledge of forestry BMP's," Water, Air, and Soil Pollution: Focus, vol. 4, no. 1, pp. 235-243, 2004.

[22] R. A. Kluender, T. L. Walkingstick, and J. C. Pickett, "The use of forestry incentives by non-industrial forest landowner groups: is it time for a reassessment of where we spend our tax dollars?" Natural Resources Journal, vol. 39, no. 4, pp. 799-818, 1999.

[23] M. A. Kilgore and C. R. Blinn, "Policy tools to encourage the application of sustainable timber harvesting practices in the United States and Canada," Forest Policy and Economics, vol. 6, no. 2, pp. 111-127, 2004.

[24] M. A. Kilgore, J. L. Greene, M. G. Jacobson, T. J. Straka, and S. E. Daniels, "The influence of financial incentive programs in promoting sustainable forestry on the nation's family forests," Journal of Forestry, vol. 105, no. 4, pp. 184-191, 2007.

[25] A. L. Paula, C. Bailey, R. J. Barlow, and W. Morse, "Landowner willingness to supply timber for biofuel: results of an Alabama survey of family forest landowners," Southern Journal of Applied Forestry, vol. 35, no. 2, pp. 93-97, 2011.

[26] M. B. Miles and A. M. Huberman, Eds., An Expanded Sourcebook, Qualitative Data Analysis, Sage, Thousand Oaks, Calif, USA, 2nd edition, 1994.

[27] J. Corbin and A. Strauss, Basics of Qualitative Research: Techniques and Procedures for Developing Grounded Theory, Sage, Thousand Oaks, Calif, USA, 2008.

[28] D. E. Gray, Doing Research in the Real World, Sage, London, UK, 2004.

[29] A. L. Husak, S. C. Grado, and S. H. Bullard, "Perceived values of benefits from Mississippi's forestry Best Management
Practices," Water, Air, and Soil Pollution: Focus, vol. 4, no. 1, pp. 171-185, 2004.

[30] P. V. Ellefson, M. A. Kilgore, and M. J. Phillips, "Monitoring compliance with BMPs: the experience of state forestry agencies," Journal of Forestry, vol. 99, no. 1, pp. 11-19, 2001.

[31] G. G. Ice, E. Schilling, and J. Vowell, "Trends for forestry best management practices implementation," Journal of Forestry, vol. 108, no. 6, pp. 267-273, 2010.

[32] M. A. Arthur, G. B. Coltharp, and D. L. Brown, "Effects of Best Management Practices on forest streamwater quality in eastern Kentucky," Journal of the American Water Resources Association, vol. 34, no. 3, pp. 481-495, 1998.

[33] J. L. Schuler and R. D. Briggs, "Assessing application and effectiveness of forestry best management practices in New York," Northern Journal of Applied Forestry, vol. 17, no. 4, pp. 125-134, 2000.

[34] W. M. Aust and C. R. Blinn, "Forestry best management practices for timber harvesting and site preparation in the eastern United States: an overview of water quality and productivity research during the past 20 years (1982-2002)," Water, Air, and Soil Pollution: Focus, vol. 4, no. 1, pp. 5-36, 2004.

[35] B. Holt, Perception to inception: assessing contractor capacity to utilize woody biomass for energy production in the Southern Willamette Valley, Oregon, M.S. thesis, 2008.

[36] S. K. Eliason, C. R. Blinn, and J. A. Perry, "Natural resource professional continuing education needs in Minnesota: focus on forest management guidelines," Northern Journal of Applied Forestry, vol. 20, no. 2, pp. 71-78, 2003.

[37] T. Dietz, P. C. Stern, and R. W. Rycroft, "Definitions of conflict and the legitimation of resources: the case of environmental risk," Sociological Forum, vol. 4, no. 1, pp. 47-70, 1989.

[38] A. L. Dirkswager, M. A. Kilgore, D. R. Becker, C. Blinn, and A. $\mathrm{Ek}$, "Logging business practices and perspectives on harvesting forest residues for energy: a minnesota case study," Northern Journal of Applied Forestry, vol. 28, no. 1, pp. 41-46, 2011.

[39] M. E. Harmon, J. F. Frankin, F. J. Swanson et al., "Ecology of course woody debris in temperate ecosystems," Advances in Ecological Research, vol. 15, pp. 133-302, 1986.

[40] B. Freedman, V. Zelazny, D. Beaudette et al., "Biodiversity implications of changes in the quantity of dead organic matter in managed forests," Environmental Reviews, vol. 4, no. 3, pp. 238-265, 1996.

[41] M. L. Hunter, Maintaining Biodiversity in Forest Ecosystems, Cambridge University Press, Cambridge, UK, 1999.

[42] W. Jia-bing, G. De-xin, H. Shi-jie, Z. Mi, and J. Changjie, "Ecological functions of coarse woody debris in forest ecosystem," Journal of Forestry Research, vol. 16, no. 3, pp. 247252, 2005.

[43] D. B. Botkin, Discordant Harmonies: A New Ecology for the Twenty-First Century, Oxford University Press, New York, NY, USA, 1990.

[44] T. R. Peterson, Sharing the Earth: The Rhetoric of Sustainable Development, University of South Carolina Press, Columbia, SC, USA, 1997.

[45] G. R. Hess and D. Zimmerman, "Woody debris volume on clearcuts with and without satellite chip mills," Southern Journal of Applied Forestry, vol. 25, no. 4, pp. 173-177, 2001.

[46] C. E. Moorman, K. R. Russell, G. R. Sabin, and D. C. Guynn, "Snag dynamics and cavity occurrence in the South Carolina Piedmont," Forest Ecology and Management, vol. 118, no. 1-3, pp. 37-48, 1999. 
[47] D. A. Patrick, M. L. Hunter, and A. J. K. Calhoun, "Effects of experimental forestry treatments on a Maine amphibian community," Forest Ecology and Management, vol. 234, no. 13, pp. 323-332, 2006.

[48] Pennsylvania Department of Conservation and Natural Resources, "Guidance from Harvesting Woody Biomass for Energy in Pennsylvania," 2008, http://www.dcnr.state.pa.us/ PA_Biomass_guidance_final.pdf.

[49] R. E. Matland, "Synthesizing the implementation literature: the ambiguity-conflict model of policy implementation," Journal of Public Administration Research and Theory, vol. 5, no. 2, pp. 145-174, 1995.

[50] "Market Facts. Market Trend. July 2002 British Columbiawide public opinion tracking poll: Public perceptions and attitudes towards RPFs and forest management," 2002, http:// www.abcfp.ca/publications_forms/publications/documents/ 2002_opinion_poll.pdf.

[51] J. W. Thomas, "Are there lessons for Canadian foresters lurking south of the border?" Forestry Chronicle, vol. 78, no. 3, pp. 382-387, 2002.

[52] M. K. Luckert, "Why are enrollments in Canadian forestry programs declining?" Forestry Chronicle, vol. 80, no. 2, pp. 209-214, 2004.

[53] M. J. Keefer, J. C. Finley, A. E. Luloff, and M. E. McDill, "Characterizing loggers' forest management decisions," Journal of Forestry, vol. 100, no. 6, pp. 8-15, 2002.

[54] A. F. Egan, C. C. Hassler, and S. T. Grushecky, "Logger certification and training: a view from West Virginia's logging community," Forest Products Journal, vol. 47, no. 7-8, pp. 4650, 1997.

[55] J. C. Bliss, "Public perceptions of clearcutting," Journal of Forestry, vol. 98, no. 12, pp. 4-9, 2000.

[56] A. Egan and D. Taggart, "Who will log? Occupational choice and prestige in New England's North woods," Journal of Forestry, vol. 102, no. 1, pp. 20-25, 2004.

[57] R. A. Williams, D. E. Voth, and C. Hitt, "Arkansas' NIPF landowners' opinions and attitudes regarding management and use of forested property," in Symposium on Non-Industrial Private Forests: Learning for the Past, Prospects for the Future, pp. 230-237, 1996.

[58] J. C. Bliss, S. K. Nepal, R. T. Brooks Jr., and M. D. Larson, "Forestry community or grandfalloon?" Journal of Forestry, vol. 92, no. 9, pp. 6-10, 1994. 

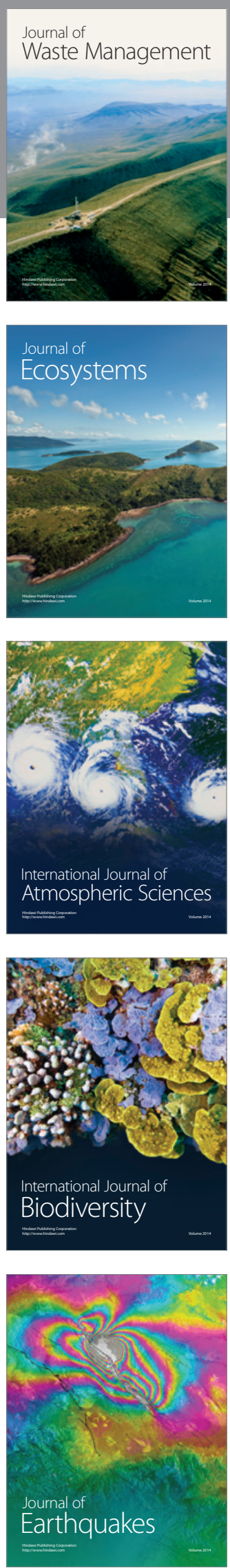
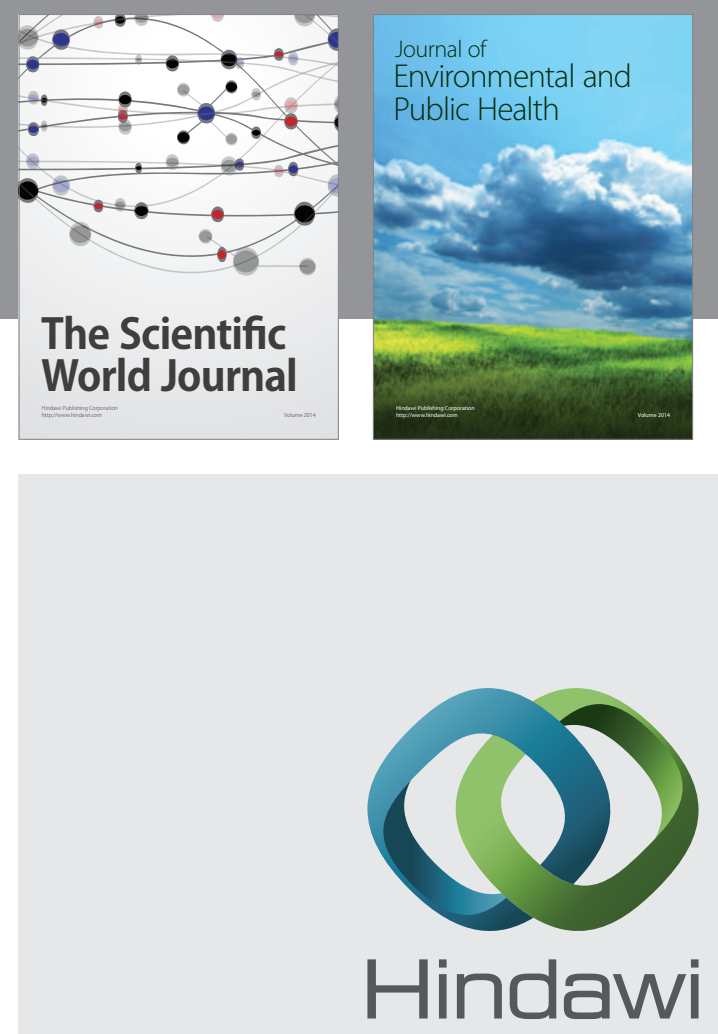

Submit your manuscripts at

http://www.hindawi.com
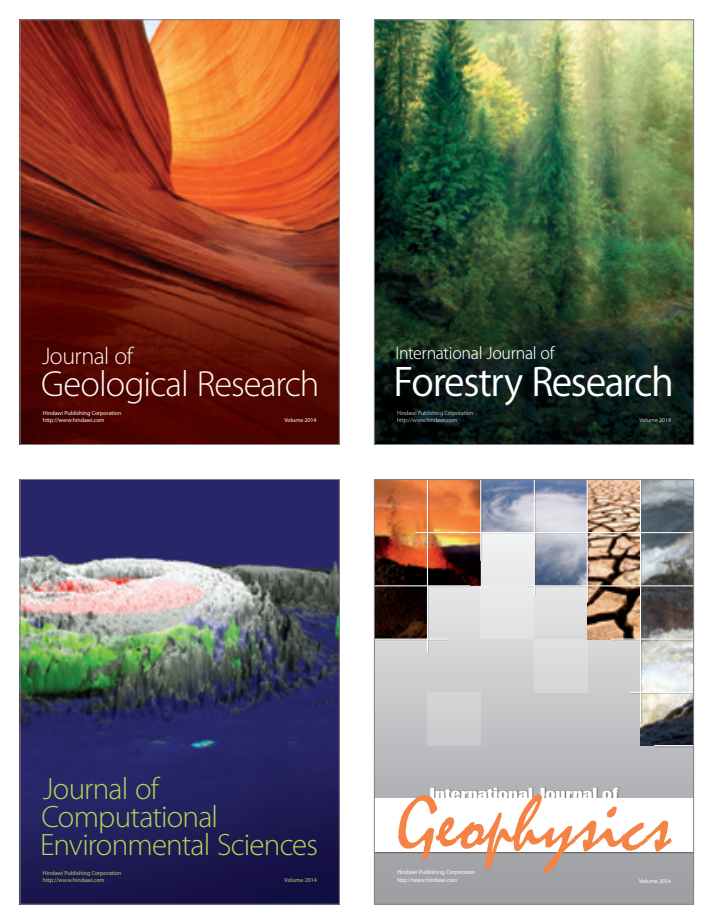
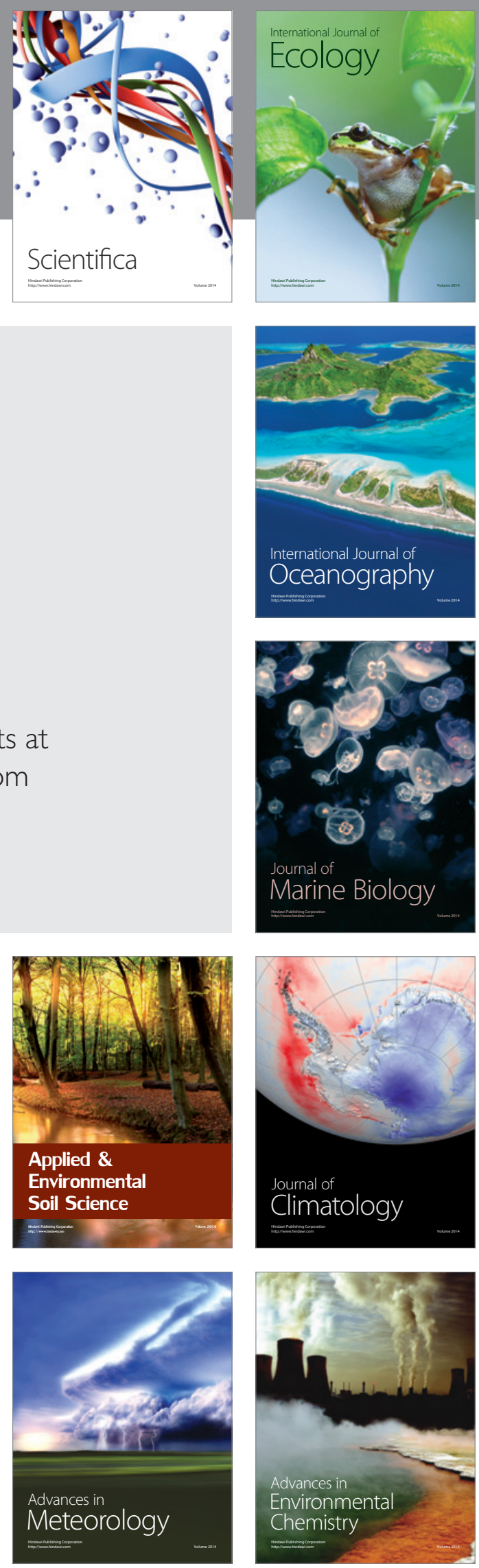